\title{
Direct payments for biodiversity conservation in developing countries: practical insights for design and implementation
}

\author{
SARAH MiLne and EduARD NiESTEN
}

\begin{abstract}
The idea of direct payments for biodiversity conservation in developing countries has generated much debate. Despite substantial experience with related economic instruments in high-income countries such approaches are rare in tropical developing countries, where conservation action is most urgently needed. We explore current experience with the application of direct payments in developing countries through an extensive review and subsequent analysis of the efforts of Conservation International. Our review identifies a broad spectrum of possible direct payment contracts. However, we focus on those involving international conservation interests. Firstly, we develop a framework for the design of direct payment applications, addressing four major aspects: contractual arrangements, definition of conservation services, performance payments, and monitoring and enforcement systems. Secondly, we discuss implementation issues, highlighting the need to consider social factors such as participatory processes, property rights, local institutions and contract legitimacy. Finally, we discuss important considerations for future payment schemes. These include the need for social responsibility, as well as rigorous assessments of effectiveness. We conclude that direct payments show potential as an innovative tool for engaging local communities or resource users in conservation and as a mechanism for channelling global investments in biodiversity conservation services to site-based initiatives.
\end{abstract}

Keywords Communities and conservation, conservation practice, developing countries, direct payments, economic incentives.

\section{Introduction}

$\mathrm{D}$ irect payments for biodiversity conservation are essentially contracts whereby custodians of natural resources are rewarded for biodiversity protection. The idea has gained prominence since the Society for Conservation Biology symposium Direct payments as an alternative approach to conservation investment (SCB, 2002) and is now addressed in a growing body of literature (Simpson \&

SARAH Milne (Corresponding author) Department of Geography, University of Cambridge, Downing Place, Cambridge, CB2 3EN, UK. E-mail sam99@cam.ac.uk

EduARd Niesten Conservation International, Arlington, USA.

Received 9 March 2008. Revision requested 23 May 2008.

Accepted 25 July 2008.
Sedjo, 1996; Ferraro, 2001; Ferraro \& Kiss, 2002; Hardner \& Rice, 2002; Wunder, 2007). The concept has sparked interest and debate among policy makers, donors and conservation practitioners. Enthusiasts promote direct payments for their potential to diffuse the complexities facing conservation in developing countries and to increase the effectiveness and efficiency of conservation investments. However, detractors have raised concerns about the feasibility, sustainability and potential social impacts of direct payments (Swart, 2003; Romero \& Andrade, 2004; Hutton et al., 2005). Here we attempt to address the debate empirically. We review examples of direct payments from practice, suggest a practical framework to guide design and discuss key implementation issues for practitioners.

\section{Theory and debate}

The simplicity of the direct payments approach is appealing: it provides a contractual mechanism whereby conservationists can reward local resource users for the delivery of biodiversity conservation services (Ferraro, 2001). It is also known as conservation contracting, conservation performance payments and conservation incentive agreements (Niesten \& Rice, 2004). These may be considered versions of schemes for payments for environmental services that involve "a voluntary conditional agreement between at least one 'seller' and one 'buyer' over a well defined environmental service" (Wunder, 2007). Here, we consider direct payments as a subset of payments for environmental services approaches that meet the following criteria: (1) payments are made explicitly for biodiversity conservation, rather than for other environmental services such as carbon sequestration or watershed maintenance (although we consider cases where services are bundled); (2) payments are at least partially funded by philanthropic global investors or international donors and do not rely on local users of environmental services or public funds; and (3) payments are for the protection of existing biodiversity, not for restoration (Pagiola et al., 2004; Wunder, 2005). Thus, direct payments typically rely upon NGOs as intermediaries and require ongoing payments for biodiversity protection from external sources. These arrangements lend themselves to the establishment of long-term financing mechanisms, now part of an emerging vision for global-scale conservation (Kiss, 2004).

The idea of direct payments derives from economic theory and is informed by practical insights from business 
and the private sector. Essentially, payments for biodiversity conservation function like market transactions in the form of contracts for service delivery (Ferraro, 2001). The seller is typically a local resource user (e.g. farmer, local community, indigenous custodian, government department) who is responsible for delivering biodiversity services; the buyer is the organization or individual seeking to conserve biodiversity. The terminology of contracts and service delivery is not necessarily used in practice but provides a theoretical framework. The aim is to create incentives for local resource users or other bodies to conserve biodiversity by making conservation a competitive land-use option (Ellison, 2003; Kiss, 2004). Thus, an appreciation of market-driven behaviour informs the approach, as well as a sense of competing in a market for resources against extractive industries (Niesten \& Rice, 2004). In this way, direct payment initiatives respond to numerous calls for the use of market-based mechanisms in conservation to pay for biodiversity services that were previously provided in kind by often poor resource users (Balmford et al., 2002; Landell-Mills \& Porras, 2002; Pagiola et al., 2002).

The distinguishing feature of direct payments is that they are performance-based, or quid pro quo: if local bodies fail to deliver the conservation services as agreed then payments will be withdrawn or reduced. Thus, benefits provided to local bodies for conservation services are conditional. This is the fundamental difference between direct payments and approaches such as integrated conservation and development projects (ICDPs) or sustainable use initiatives that seek to combine resource extraction and human development with biodiversity conservation. Direct payments instead represent a change in perspective by decoupling the goals of conservation and development while recognizing the opportunity cost of conservation for local bodies. Such local bodies negotiate directly with conservationists rather than being left constrained as project participants. Thus, the approach recognizes that conservation cannot be achieved without addressing human needs but is distinct from ICDP models because development incentives are conditional upon conservation performance.

Despite the potential for direct payments to invigorate approaches to conservation and development the idea has not received unanimous support among practitioners because of both ideological and practical concerns. Ideological dimensions involve concerns about market-based approaches to conservation (Swart, 2003; Lovera, 2004) and asymmetrical relationships between powerful global conservation organizations and potentially vulnerable local bodies (Romero \& Andrade, 2004). There are also concerns that unfair negotiations and contracts may erode local livelihoods and displace customary ownership and management of natural resources (Hutton et al., 2005). These concerns have caused sceptics to reject direct payment policies without considering evidence from practice (Wunder, 2006). Here we review practical experiences, noting where theory and reality diverge.

\section{Direct payments in practice}

Direct payment approaches face numerous practical challenges. Many of these are familiar, and relate to conditions faced by conservationists in developing countries regardless of the strategy employed. They include weak governance, poorly defined property rights, limited human capacity, and conflicts between conservation and human development. Other challenges are particular to direct payments, and include: (1) institutional arrangements that permit negotiation and implementation of contracts; (2) establishment and maintenance of legal, political and social conditions required for contracts; (3) management of potential social impacts; and (4) the ability to adjust contracts and incentives to changing conditions. We use evidence from practice to examine design- and implementation-related challenges of direct payments. We outline a practical framework to guide design and discuss key issues that arise in practice, in turn questioning some theoretical notions that underlie direct payment policies. Questions about the effectiveness and impacts of direct payments in the longterm are beyond the scope of this article and require further research.

\section{Research methods and data}

We conducted a review of direct payment applications in developing countries. Cases were identified through interviews with practitioners in 2006-2007 in USA and UK, and through internet searches guided by existing databases and reviews (Ferraro, 2008). A total of 48 cases of payment schemes for biodiversity services in developing countries were identified; $77 \%$ of these ( 37 cases) were at least partially funded by international donors and are thus the subject of this article. The remaining cases were either locally or publicly funded and require separate analysis. Within the set of cases that involve international funding the majority engage communities as service providers (64.9\%), and agreements with governments and individuals are less frequent (13.5 and $21.6 \%$, respectively). The high frequency of community-based initiatives may be an artifact of the sample, indicating the nature of land tenure in remote high biodiversity areas but further investigation is required. Subsequent analysis in this article focuses largely on community-based agreements in the context of conservation and development as these are most frequent.

Table 1 provides an illustrative sample of cases involving international buyers of biodiversity services. Cases in the table were selected to demonstrate distinct modalities as well as geographical scope. Case selection was influenced by data availability: we only list cases for which project 
TABLE 1 Illustrative sample and typology of direct payments schemes in developing countries.

\begin{tabular}{|c|c|c|c|c|c|}
\hline Lead organization & Location & Conservation goals & Nature of contract & Payments or benefits & Project status \\
\hline \multicolumn{6}{|c|}{1 Habitat or area-based contracts } \\
\hline \multicolumn{6}{|c|}{ 1.1 Community as service provider: leases or agreed management practices on communal land } \\
\hline $\begin{array}{l}\text { Conservation International } \\
\text { (CI); Conservation } \\
\text { Stewards Program }\end{array}$ & $\begin{array}{l}\text { Ecuador, Burma, } \\
\text { Madagascar, } \\
\text { Cambodia, China, } \\
\text { Peru, Venezuela }\end{array}$ & $\begin{array}{l}\text { Habitat \& forest } \\
\text { protection }\end{array}$ & $\begin{array}{l}\text { Annual agreements between CI \& } \\
\text { communities, often implemented } \\
\text { through local partners (in China, } \\
\text { the government is } \\
\text { co-implementer). Services include } \\
\text { forest protection \& conservation } \\
\text { management activities. }\end{array}$ & $\begin{array}{l}\text { Schools, infrastructure, } \\
\text { agricultural assistance, wages for } \\
\text { community patrolling }\end{array}$ & $\begin{array}{l}\text { Various stages } \\
2005-2007\end{array}$ \\
\hline $\begin{array}{l}\text { Durrell Wildlife } \\
\text { Conservation Trust } \\
\text { (Durbin et al., 2005) }\end{array}$ & $\begin{array}{l}\text { Madagascar, } \\
\text { Menabe }\end{array}$ & $\begin{array}{l}\text { Habitat protection } \\
\text { for endemic species, } \\
\text { especially the giant } \\
\text { jumping rat } \\
\text { Hypogeomys } \\
\text { antimena }\end{array}$ & $\begin{array}{l}\text { Annual agreements between the } \\
\text { Trust \& local communities. Services } \\
\text { include participatory ecological } \\
\text { monitoring \& forest protection. }\end{array}$ & $\begin{array}{l}\text { Benefits depend on conservation } \\
\text { performance (as indicated by } \\
\text { biodiversity monitoring data) \& } \\
\text { include bicycles, buildings or } \\
\text { generators }\end{array}$ & $\begin{array}{l}\text { Since 2003, } 10 \\
\text { communities }\end{array}$ \\
\hline $\begin{array}{l}\text { Conservation } \\
\text { International }\end{array}$ & Fiji & Create a protected area & $\begin{array}{l}\text { 99-year lease from indigenous } \\
\text { landowners (communal title } \\
\text { holders) to avert logging }\end{array}$ & $\begin{array}{l}\text { Lease \& foregone timber royalty } \\
\text { payments made to community; } \\
\text { additional contributions to a local } \\
\text { conservation \& development trust }\end{array}$ & $\begin{array}{l}\text { Negotiations } \\
2006-2007\end{array}$ \\
\hline $\begin{array}{l}\text { WWF; Mexican Fund for } \\
\text { the Conservation of } \\
\text { Nature (Missrie \& } \\
\text { Nelson, 2005) }\end{array}$ & Mexico & $\begin{array}{l}\text { Habitat protection for } \\
\text { monarch butterfly } \\
\text { Danaus plexippus }\end{array}$ & $\begin{array}{l}\text { Communities receive payments to } \\
\text { forgo logging permits \& protect } \\
\text { habitat for the monarch butterfly in } \\
\text { the core zone of the protected area }\end{array}$ & $\begin{array}{l}\text { The Monarch Butterfly } \\
\text { Conservation Fund generates } \\
\text { interest that covers payments to } \\
\text { communities }\end{array}$ & Since 2002 \\
\hline \multicolumn{6}{|c|}{ 1.2 Government as service provider: concessions or leases on public land } \\
\hline $\begin{array}{l}\text { Conservation } \\
\text { International }\end{array}$ & Guyana & $\begin{array}{l}\text { Protect forest } \\
(80,000 \text { ha })\end{array}$ & $\begin{array}{l}\text { 30-year Timber Sales Agreement, } \\
\text { comparable to an active timber } \\
\text { concession }\end{array}$ & $\begin{array}{l}\text { Payment of acreage fees \& } \\
\text { royalties to Government. } \\
\text { Separate benefits also paid to } \\
\text { a voluntary community } \\
\text { investment fund. }\end{array}$ & Since 2002 \\
\hline $\begin{array}{l}\text { Burung Indonesia, RSPB \& } \\
\text { BirdLife International } \\
\quad \text { (RSPB, 2007) }\end{array}$ & $\begin{array}{l}\text { Indonesia, } \\
\text { Sumatra }\end{array}$ & $\begin{array}{l}\text { Restore \& protect } \\
\text { Harapan rainforest } \\
(101,000 \mathrm{ha})\end{array}$ & $\begin{array}{l}100 \text {-year ecosystem restoration } \\
\text { license obtained from Government } \\
\text { of Indonesia }\end{array}$ & $\begin{array}{l}\text { Concession payments made to } \\
\text { Government. Management costs } \\
\text { covered by the NGO alliance, } \\
\text { which plans to establish an } \\
\text { endowment fund. }\end{array}$ & Since 2007 \\
\hline $\begin{array}{l}\text { RSPB \& Conservation } \\
\text { Society of Sierra Leone } \\
\text { (D. Siaffa, pers. comm.) }\end{array}$ & Sierra Leone & $\begin{array}{l}\text { Protect the Gola } \\
\text { Forest Reserves } \\
\text { through a conservation } \\
\text { concession }(74,800 \mathrm{ha})\end{array}$ & $\begin{array}{l}\text { A project partnership consists of the } \\
\text { Government's Forestry Division \& } \\
\text { seven chiefdom communities; both } \\
\text { parties manage the forest resources. }\end{array}$ & $\begin{array}{l}\text { Royalties of USD } 5.33 \mathrm{ha}^{-1} \text { to } \\
\text { Forestry Division if the forest is } \\
\text { protected. Community royalties } \\
\text { also paid through a benefit } \\
\text { sharing agreement for local } \\
\text { development projects. A trust } \\
\text { fund will be established to cover } \\
\text { ongoing costs. }\end{array}$ & $\begin{array}{l}\text { Since 2004; Gola } \\
\text { Forest Programme } \\
\text { now approved for } \\
2007-2012\end{array}$ \\
\hline
\end{tabular}




\subsection{Individuals as service providers: leases or agreed management practices on private land} Programme (WCCSA

South Africa,

Protect biodiversity

2006)

Wildlife Conservation Lease Kenya,

Programme (Gichohi, Kitengela

2003)

Fundacion Natura Bolivia Bolivia, (NGO facilitator), with Los Negros

US Fish \& Wildlife

Service (Asquith et al., 2008)

\begin{tabular}{|c|c|c|}
\hline \multicolumn{3}{|c|}{ 2. Species-specific contracts: not area-based, various service providers } \\
\hline $\begin{array}{l}\text { Conservation } \\
\text { International }\end{array}$ & $\begin{array}{l}\text { Cambodia, } \\
\text { Koh Kong }\end{array}$ & $\begin{array}{l}\text { Prevent collection of } \\
\text { dragon fish fingerlings } \\
\text { Scleropages formosus } \\
\text { from spawning pools }\end{array}$ \\
\hline $\begin{array}{l}\text { Tigris Foundation \& } \\
\text { Phoenix Fund (Hotte, } \\
\text { 2006) }\end{array}$ & Russia & $\begin{array}{l}\text { Protect Amur leopard } \\
\text { Panthera pardus } \\
\text { orientalis \& Siberian } \\
\text { tiger Panthera tigris } \\
\text { altaica }\end{array}$ \\
\hline $\begin{array}{l}\text { Wildlife Conservation } \\
\text { Society (WCS) } \\
\text { (Svadlenak-Gomez et al., } \\
\text { 2007) }\end{array}$ & $\begin{array}{l}\text { Cambodia, } \\
\text { Preah Vihear }\end{array}$ & $\begin{array}{l}\text { Protect globally } \\
\text { threatened large } \\
\text { waterbirds (at least } \\
\text { six species) }\end{array}$ \\
\hline $\begin{array}{l}\text { Snow Leopard Trust } \\
\quad \text { (Mishra et al., 2003) }\end{array}$ & $\begin{array}{l}\text { Mongolia, } \\
\text { Kyrygzstan }\end{array}$ & $\begin{array}{l}\text { Ban on poaching } \\
\text { snow leopard Uncia } \\
\text { panthera \& protection } \\
\text { of their prey }\end{array}$ \\
\hline
\end{tabular}

Watamu Turtle Watch

Kenya

Program (WTW, 2007) on private lands

Formal agreements between

CapeNature \& individual

landowners, enabled by national legislation

Maintenance of open Voluntary annual agreements with areas for wildlife \& grazing

Protect threatened cloud-forest habitat for 11 migratory birds (2,774 ha) pastoral landowners to lease their land

Annual contracts with landowners to prohibit tree cutting, hunting \& forest clearing. Services bundled with user-financed watershed protection.

Annual renewable agreement between community (through representative committees), local authorities \& CI

Private deer farmers enter agreements with Phoenix fund to not harm tigers or leopards \& to provide biological data

Multiple contracts between WCS \& community members. Individuals rewarded for reporting nests \& for monitoring \& protection of chicks. local herders, Snow Leopard Trust, local NGO Snow Leopard Conservation Fund \& government

Protection of marine turtles, predominantly green turtle Chelonia mydas

Agreement with local communities \& Kenya Wildlife Service to protect turtle nests through financial incentives
Annual renewable contracts between

Structured payments made to

Individuals receive USD 1 per of USD 1 per day if $\operatorname{chick}(\mathrm{s})$

Fishermen compensated for net landowners, using a combination of public \& international funds

Residents paid three times per year, on the basis of an annual lease of USD 4 per acre $(=0.41$ ha $)$

Payments are predominantly as projects, in this case training \& equipment for apiculture.

Independent yearly monitoring is conducted, with sanctions for non-compliance.

Combination of in-kind benefits (school, agricultural assistance) $\&$ cash into community fund

Farmers compensated in cash for livestock kills \& receive in-kind farming assistance day for nest protection $\&$ a bonus successfully fledge, up to USD 400 per person per year Snow Leopard Trust purchases wool products from herders at a premium; $20 \%$ bonus is paid to individual herders if

conservation commitments are honoured

Since 2003,

35 contracts

Since 2000,

115 households

Since 2003,

46 farmers

Since 2005,

one agreement

Since 1999 but deer farming now declining

Since 2003,

115 local people

Since 1998,

$>400$ families

Individuals paid for nest

Started in 2000, protection, with additiona

60 nests releases 
websites, formal reports or published material are available. The table categorizes cases as follows: category (1) is for habitat or area-based contracts that involve changes in land management, and category (2) is for species-specific contracts that require targeted actions such as nest protection or hunting bans but are not area-based. Within category (1), three different service providers are identified that generally reflect land tenure arrangements: (1.1) communities, (1.2) governments and (1.3) individuals. Various service providers exist within Category (2) but they often occur in combination and have been aggregated for simplicity.

In addition to the review we rely on primary data derived from the experiences of Conservation International with the application of conservation concessions and incentives agreements in eight countries (Table 1). We employed research methods from qualitative social sciences, including participant observation, interviews with project staff and reference to project documents. Data therefore consisted of diverse accounts from practitioners rather than structured or positivist assessments of conservation outcomes.

\section{A practical framework for direct payment applications}

Our review enabled us to characterize key components of direct payment schemes and to develop a practical framework for design and implementation. The framework has four components: (1) contract design, (2) definition of biodiversity conservation services, (3) delivery of performance payments or benefit packages and (4) performance monitoring and sanctions. This is not necessarily a chronological sequence for implementation. Rather, our findings highlight key terms and decisions that need to be addressed when designing agreements.

\section{(1) Contract design}

Direct payment contracts vary depending upon the social, political and legal characteristics of each site. All contracts must comply with local laws but specific relevant legislation is often absent, leaving considerable flexibility. Contract design is also influenced, both spatially and institutionally, by the particular threats or opportunities at each site. There is a spectrum of possible contractual arrangements, indicated by the categories in Table 1 . Some arrangements are: conservation organizations negotiate with local communities through committees, councils or traditional leaders (Cambodia, Ecuador, China); conservationists make agreements with individual land owners, often on private lands (South Africa, Bolivia); conservationists use national legislation to lease land from indigenous groups (Fiji) or government (Guyana). In addition, our examples indicate that direct payments can serve as a protected area management tool as well as a mechanism to conserve buffer zones and corridors that are not formally protected.

Regardless of the variation in contracts we suggest a set of critical features that require precise definition: parties and stakeholders in the agreement, roles and responsibilities of parties, duration of agreements, and systems of performance monitoring, payments, sanctions and decisionmaking. Definition of parties' roles and responsibilities forces conservation organizations to be clear about how they engage with local bodies. Conservation practitioners must decide what style of relationship to pursue with communities, ranging from partnership within a conservation agreement to a more business-like transaction.

\section{(2) Definition of biodiversity conservation services}

The viability of conservation agreements depends on clearly defined conservation services, which may entail the protection of a single species, several groups of species or an entire site. Critically, conservation performance must be quantitatively defined and monitored over time periods suitable for contract management. This means that the available performance metrics effectively define conservation services. Research is required to develop practical and meaningful conservation performance metrics that can be generalized across sites. One suggestion has been to use number of hectares protected (Ferraro \& Kiss, 2002) but this does not measure biodiversity conservation per se. For now, the burden falls upon practitioners to define and measure conservation performance in a way that makes practical sense for each location.

Our examples (Table 1) demonstrate that definition of conservation performance is site dependent. Most agreements focus on well-bounded and relatively small sites that require urgent conservation action. In the case of site protection, boundaries are best defined by natural features such as rivers or wetlands, rather than as lines on a map. Examples include turtle nesting beaches (Kenya), fish spawning pools (Conservation International, Cambodia) or bird nesting areas (Wildlife Conservation Society, Cambodia). Alternatively, sites may be defined by existing cultural features such as sacred sites (China) or traditionally cultivated cardamom forests (Cambodia). In cases where conservation targets are not self-evident, such as the protection of general forest areas, boundary demarcation is essential. In Cambodia boundaries on maps were not enough to ensure agreement compliance on the ground; investments in sign-posting and demarcation were required to define and objectively monitor conservation performance.

Finally, monitoring conservation performance usually does not involve direct measurement of biodiversity because of technical and financial constraints of biodiversity monitoring (Salafsky et al., 2002). Rather, conservation performance is most easily monitored using proxy indicators 
that measure human behaviour: presence or absence of wildlife snares, occurrence or not of forest clearing or accomplishment of conservation management activities. In these cases, service providers cannot be responsible for external factors affecting biodiversity such as fires or seasonal variation. Furthermore, assumptions about the causal links between conservation actions and desired results are required. Biodiversity monitoring therefore remains necessary to track whether long-term conservation goals are being achieved. Only rarely can conservation performance be measured using biological indicators. For example, two schemes conditioned payments on frequency of nesting sites of threatened species: the Bengal florican Houbaropsis bengalensi in Cambodia and sea turtles in Kenya. In addition, some cases use evidence of priority species to reward bonus payments on top of existing benefit packages, such as for lemurs in Madagascar (J. Ratsimbazafy, pers. comm.).

\section{(3) Delivery of performance payments or benefit packages}

The value and form of performance payments depend on local context and negotiations rather than market-based prices for biodiversity. The process of negotiating agreements results in decisions about the benefit amount, the form that it will take, distribution mechanisms and penalties or sanctions if conservation performance standards are not met. Agreements are struck when the amount of benefit that local communities are willing to accept is at least equal to the amount that conservation organisations are willing to pay (Ferraro \& Simpson, 2002).

In practice, many negotiations incorporate the idea that payments should compensate local bodies for the opportunity cost of conservation. That is, payments should equal 'the value of all goods or services that local actors must give up ... to meet conservation goals' (Niesten \& Rice, 2004). For example, communities in Cambodia were offered payments for protecting dragon fish Scleropages formosus that equalled the amount of income forgone by not harvesting. This provided a clear basis for negotiation and was understood readily by community members. Payments designed to match the opportunity cost of conservation featured in several projects, including in Burma, Madagascar (B. Rajaspera, pers. comm.) and Russia (Hotte, 2006). However, determination of benefit amounts includes factors beyond financial opportunity cost. In some cases communities already value conservation benefits and therefore seek payment amounts less than forgone income from timber or wildlife harvests. For example, relatively small benefit packages made conservation desirable to communities in Ecuador and China because of local interest in protecting indigenous territory or community resources from outsiders. In other cases, payment amounts exceeded opportunity costs because they included additional funds to cover service provision, such as community patrolling and boundary demarcation in Cambodia.

Most examples combined cash payments and in-kind benefits. Cash payments are generally made to community funds that support community development investments. In most cases investments in agriculture, health and education feature in benefit packages, and wages for conservation activities represent another common form of cash benefit. Benefit packages can also take the form of alternative livelihood activities (Venezuela, Ecuador) but this risks a return to ICDP dynamics if practitioners seek a self-sustaining harmonization of conservation and development. Regardless, the key is to identify a benefit value acceptable to both parties. Cash payments are advantageous because amounts can be adjusted based upon conservation performance. But it has been difficult to convince donors and practitioners of the utility of cash payments, even managed through local institutions, and debate continues about potential social impacts (Harvey et al., 2005).

Finally, conservation agreements can offer advantages beyond performance benefits. For communities a longterm relationship with an external organization or source of funds may be valued because it reduces vulnerability and can facilitate relations with other development partners. Long-term agreements can provide access to networks, both in civil society and government, and the presence of a third party can assist with mediation or conflict resolution if necessary. In Ecuador the brokering of agreements between Conservation International, development NGOs and the community produced desirable social outcomes. The processes of external facilitation and negotiation helped the community achieve development goals (e.g. installing water pipes) that had previously stalled because of internal conflicts (A. Bruner, pers. comm.).

\section{(4) Performance monitoring and contract enforcement}

Conservation agreements require three kinds of monitoring: the status of biodiversity and conservation targets, compliance with conservation services commitments, and socio-economic changes and impacts. Social and biological monitoring are primarily useful for adaptive management (Salafsky et al., 2002) and compliance monitoring is essential for contract implementation. The contract terms for all parties must be monitored systematically and objectively. Performance data are used to determine whether sanctions are implemented in cases of unsatisfactory performance. For example, a forest protection agreement in Cambodia was violated in 2006 (c. 12 ha of forest cleared out of $>100$ hectares protected), leading to reduced benefits for the commune in 2007 by USD 1,000 or two head of buffalo (c. $10 \%$ reduction). Compliance monitoring requires substantial investment and technical capacity, and 
is ideally conducted by an independent third party. This ensures objective performance assessment and avoids potential problems with biased data collection that may occur with internal monitoring.

Monitoring can be performed by parties such as government rangers, local police, community patrol teams, research biologists and NGO staff, often in combination. Although substantial, costs of monitoring should not be considered as a particular burden of direct payment schemes. Monitoring activities provide vital income and capacity building opportunities to local communities and thus form part of benefit packages. In Cambodia and China community-based monitoring programmes used c. $20 \%$ of conservation budgets. Conservation initiatives of all kinds require investments in monitoring to track activities and impacts (Ferraro \& Pattanayak, 2006) but because conservation contracts require monitoring for functional reasons it is particularly important to allocate adequate technical and financial resources to monitoring. Weak or biased performance monitoring undermines agreements and makes it difficult to ensure accountability to conservation investors or donors. For example, one agreement for forest protection in Cambodia was undermined by sub-standard monitoring because local community monitors did not report transgressions transparently. This meant that sanctions could not be implemented without jeopardizing relationships with the local community. This case highlights the potential risks of NGO-led payment schemes that depend on community partnerships, and underscores the importance of donor scrutiny in monitoring.

\section{Issues and considerations for future applications}

Implementation of direct payment initiatives requires acknowledgement that the complexities of conservation and development will still persist, despite the promise of new policy ideas. Here we draw specifically on Conservation International's experience in implementing conservation agreements with local communities to provide insights relevant to other direct payment applications in developing countries. In (1) to (4) we highlight key implementation issues (which are not necessarily considered in policy models but directly affect the feasibility of direct payment schemes). In (5) to (7) we discuss three important considerations for future initiatives.

\section{(1) Participatory processes are part of the deal}

The notion that direct payment approaches can reduce community engagement down to a simple market transaction is often unrealistic. All of the agreements that we witnessed required participatory processes both prior to and during negotiations. This enabled stakeholders to reach a common understanding of terms and actions. For example, many months of participatory land use planning were required in Cambodia to agree on definitions and boundaries for 'forest' and 'village', and to resolve conflicts over natural resources. Without this process it would not have been possible to negotiate agreements. Participatory processes are also required to agree the causes of biodiversity loss and necessary conservation action because we cannot assume that conservationists and local people understand environmental change in the same way (Fairhead \& Leach, 2003). Processes must be tailored to each site depending upon the levels of organization, social cohesion and capacity.

\section{(2) Considering property rights}

Poorly defined property rights are a significant challenge for direct payments in developing countries (Simpson \& Sedjo, 1996). Resource rights are often contested in developing countries (Western et al., 1994) and practitioners must understand resource conflicts before they can consider a direct payments approach. In all conservation agreements that we observed participatory tools were used in feasibility analysis to document resource use patterns. This is a delicate process that requires assessment of all property rights, management responsibilities and claims to resources that may apply to an area, both de facto and de jure. Consultation is required not just with local resource users but with an array of potential stakeholders such as government, concessionaires, permit holders, businesses and indigenous custodians. This should reveal both formal and informal institutions for resource management, as well as possible resource conflicts (Ostrom, 1990). Formal registration of property rights facilitates contract design and negotiation, although creative agreements based on informal institutions or de facto property rights can succeed in the short term, as in Cambodia and Peru (R. Arevalo, pers. comm.). Solutions are not always possible, however, as some property rights regimes are too fragile, dynamic or conflicted. This is frequently seen in post-conflict settings, such as Cambodia, where land-grabbing and illegal logging meant that conservation agreements were inappropriate for some sites.

\section{(3) Defining communities, designing institutions}

In community-based agreements the process of recognizing resource rights among a diverse collection of local people is a way of defining the community with whom conservation investors will negotiate. Recognizing and legitimizing resource claims is problematic because practitioners must contend with struggles over resources and the politics of often heterogeneous local communities (Agrawal \& Gibson, 1999). Every agreement is unique: communities in Cambodia 
were defined by a combination of resource use patterns and government administrative boundaries, whereas in Fiji agreements are based on formal communal land titles held by indigenous owners. Another consideration is that not all communities are defined by their physical location. For example, customary collectors of non-timber forest products in a single forested area may originate from multiple, dispersed villages (Cleaver, 200o), which can be a significant complication. Our data show that the most common conservation agreements have communities that are physically located in one place and have a direct relationship with the conservation target area. These are cases where community actions either represent a direct threat to biodiversity or can be mobilized to avert external threats. In the first case, agreement design seeks to change local behaviour that depletes biodiversity, and this is the most common form of agreement (Cambodia, Madagascar). In the second case, agreement design enables local action against external threats, such as logging or poaching by outsiders (Ecuador, China). The latter should only be considered when communities are willing to tackle external threats and conservationists can provide adequate support such as back-up law enforcement or government engagement.

The feasibility of conservation agreements depends not only on identifying and defining communities but also on their representative institutions. These institutions must negotiate agreements and sign contracts on behalf of the community. They must also raise awareness about the commitments and conditions of agreements among community members, ensure equitable distribution of costs and benefits as far as possible, and resolve conflicts as they arise. These tasks require institutions that are legitimate, functional and politically influential at both local and regional levels. Evidence from payments for environmental services and community-based conservation initiatives shows that this is a formidable challenge (Murphree, 1994; Adams \& Infield, 2003; Wunder, 2005). Our experience showed that institutional performance varied between countries and was also affected by local contextual factors (e.g. leadership, internal politics). In Cambodia local committees were responsible for managing conservation agreements, and their success depended upon their ability to demonstrate transparent decision-making and engage multiple interest groups. One committee was unable to function because of party politics, and this meant that the agreement was suspended for 2 years until conflicts were resolved. Issues of institutional design and capacity pervade all sites and should be one of the main concerns of conservation investors. Apart from formal institutional arrangements, local leaders or champions can also play an important role in securing community participation and representation. Our informants emphasized that strong community leadership was critical to the early successes of agreements in Cambodia and Kenya (Gichohi, 2003).

\section{(4) Legitimacy of agreements is a fundamental} requirement

Signatures are not sufficient to ensure that conservation agreements are implemented, especially in the context of developing countries in which legal environments are weak or in communities where verbal agreements carry more weight. Our experience revealed many factors that can cause agreements to fail. For example, the departure of key staff members from conservation organizations or key leaders from community institutions can significantly weaken agreements, as can changes in government or power structures. These scenarios were experienced in China, Cambodia and Ecuador. Agreements therefore need to be maintained in the face of changing circumstances and this requires practitioners to maintain relationships with stakeholders, demonstrate commitment, track changes in local attitudes, and ensure appropriate design and adaptation of incentives. These tasks are essential for the credibility of conservation investors and, ultimately, the legitimacy of agreements.

The concept of legitimacy can provide a guiding principle for implementation. It is relevant because conservation agreements in developing countries must satisfy complex mixtures of legal, political, cultural and social conditions to be legitimate and hence enforceable. These conditions are dynamic, and therefore maintaining legitimacy becomes an ongoing social process (Vira, 2001). The Cambodian example is pertinent because legality is frequently malleable (Van Acker, 2003) and does not provide a secure platform for conservation agreements. In this context, viability of agreements depends upon their collective acceptance, as determined by the nature of negotiation processes and institutions involved. For example, one agreement eroded when the local committee was biased in distributing benefits, and another agreement could only be legitimized once high-level government approval had been demonstrated through public ceremonies and speeches. Thus, conditions for collective acceptance of agreements vary between sites, depending on histories, cultures and individuals. Conservation practitioners must be astute in managing the social and political processes required to achieve and maintain legitimacy.

\section{(5) Socially responsible conservation investors}

The minimum responsibility of conservationists should be to ensure that direct payment agreements do not cause negative social impacts (Adams et al., 2004). This commitment is important but complex, given that agreements inevitably produce economic and social changes within dynamic contexts. Conservationists are not social engineers; they cannot redress all inequities resulting from village politics or poor governance but they can commit to 
being socially responsible. Practitioners must therefore consider the impacts of both conservation commitments and associated benefit packages. In particular, the management of cash-based and conditional benefit packages is complicated (Harvey et al., 2005; Schubert \& Slater, 2006). For example, withholding funds for a schoolteacher or health post in response to poor conservation performance may be controversial. Conservation International has not experimented with conditionality on social service benefits but staff did encounter difficulties when benefits had to be removed. For example, in Cambodia families that received buffaloes were required to give them back if they failed to meet conservation commitments. Eventually social and cultural factors made this impossible to implement, and therefore benefit packages are now adjusted annually according to performance. The design of benefit packages is also a balancing act, as there is a risk of practitioners being overly prescriptive. Experience in Cambodia showed that, although increased external involvement with the design and delivery of benefit packages resulted in higher management costs and reduced community control over decision-making, this involvement arguably led to more equitable and transparent benefit distribution. Thus, the role of conservation organizations in community decision-making over benefit packages requires careful consideration.

The challenge of achieving equitable distribution of costs and benefits in payment schemes raises issues about the social impacts of conservation practice as a whole (Brockington \& Schmidt-Soltau, 2004; Wilkie et al., 2006). To avoid undesirable environmental or social impacts, direct payments, like any other conservation initiative, must account for groups within communities that may be more negatively affected by changes, and pay attention to local institutions in communities that mediate how benefits are chosen and distributed. Examples from Cambodia are illustrative: observation suggests that poor or landless families may suffer disproportionately from restrictions on shifting agriculture under conservation agreements, and the decision by community members to purchase livestock as part of the benefits raised the difficulty of equitably sharing 12 buffaloes between 60 families (Milne, 2007). Thus, conservationists must monitor systematically the social effects of their actions, and adaptively manage agreements if unexpected negative impacts occur. Such calls for socially responsible and adaptive conservation practice are not new (Berkes, 2004; Robinson, 2006).

Finally, social responsibility does not just involve empirically measured socio-economic impacts; it also requires consideration of local custodianship and traditional or indigenous relationships to the environment. Direct payments have been criticized for their potential to alienate local residents and lock up natural assets, as in protectionist approaches to conservation (Hutton et al., 2005). However, our observations suggest that many conservation agreements have the opposite effect: community members have been empowered to conduct biodiversity monitoring (Cambodia), protect their resources through patrolling (Ecuador), and acquire exclusive user rights over areas that were formerly open access (China). Thus, communitybased agreements have potential to reinforce local custodianship over natural resources.

\section{(6) Direct incentives and the effectiveness of conservation action}

Direct payment approaches are compelling because of their potential to achieve biodiversity conservation goals more effectively than other approaches. The conservation agreements negotiated by Conservation International suggest effectiveness gains but there have been no rigorous evaluations, nor are there enough long-term cases to draw conclusions. It is encouraging that, in a relatively short period, agreements in China put 5,000 ha of forest under protection, agreements in Cambodia enabled an immediate ban on dragon fish harvesting, and negotiations in Fiji displaced logging activity within indigenous communal lands. But these cases do not prove that direct payments are more effective than other approaches. Ideally, effectiveness would be assessed using rigorous evaluation methods that compare the impacts of direct payments with other interventions and counterfactual scenarios or control sites (Ferraro \& Pattanayak, 2006). This is a challenge that requires further research.

Although our evidence does not enable evaluation of effectiveness, it does provide insights into why agreements may work better than other approaches in some circumstances. Agreements appear to focus resources on conservation goals and reduce lead times for conservation action. This may result from the way in which conservation agreements engage local bodies and motivate effort around achieving tangible results. Project staff identified a common thread whereby disillusioned projects were reinvigorated once the idea of conservation agreements was introduced. For example, a pre-existing sustainable forestry project in Ecuador never met local expectations but the situation changed rapidly when conservation agreements were proposed and negotiated (A. Bruner, pers. comm.). Similarly, in Cambodia, local stakeholders mobilized readily around agreements and were excited about the possibility of negotiating and securing benefits from conservationists who had formerly only pursed law enforcement tactics. This suggests that local bodies respond to direct incentives and opportunities for negotiation more willingly than other approaches, perhaps because they are already experienced in making deals (e.g. for timber concessions, land rentals, harvesting permits) and are not required to embrace a set of new, alien ideas for conservation purposes. These 
observations correspond with assertions that market-based mechanisms such as direct payments create incentives and motivation for biodiversity conservation better than other approaches (McNeely, 1993; Kiss, 2004).

Finally, any consideration of the effectiveness of direct payments must also identify circumstances in which the approach is unlikely to work. We have discussed several implementation difficulties that have undermined effectiveness but it is unclear whether these are a function of inexperience or deeper challenges. We propose a set of prohibitive conditions where conservation agreements are unsuitable. These conditions are where: (1) conflicts over property rights cannot be solved in the short-term, (2) potential service providers are not clearly identifiable or are unwilling to participate, (3) the nature of threats to biodiversity means that cheaper or more effective solutions are possible, and (4) service providers may incur significant risks or unacceptable social impacts. These conditions must be assessed on a case-by-case basis through feasibility studies.

\section{(7) Synergies with sustainable financing}

Practitioners are beginning to acknowledge that successful conservation will require ongoing funding from public and philanthropic sources, given that markets have failed to secure natural resources (Balmford \& Whitten, 2003). Donors need to realize that conservation cannot be achieved within 3-5 year project cycles and that long-term sustainable financing is necessary. The emerging field of conservation finance is increasingly experimenting with funding mechanisms such as project-specific endowments and trust funds, which can deliver conservation payments in perpetuity (CFA, 2006). The synergy between sustainable financing mechanisms and conservation contracting approaches has been noted (Ferraro, 2001; Kiss, 2004). That is, direct payment mechanisms offer an explicit way to channel funds and are thus suited to the establishment of endowments that can generate ongoing conservation payments. In this sense, a conservation agreement is not complete until an endowment is in place to sustain it. Experiences with Conservation International's pilot concession in Guyana are instructive, as an endowment has not been capitalized and the initiative still faces an annual fundraising burden to meet lease payments. In future, conservation contracting and sustainable financing should be coupled to create a portfolio of conservation contracts, each with its own endowed funding. Such a format would accommodate myriad fundraising options, offering a direct link between global willingness to pay for biodiversity conservation and parties able to deliver conservation services. A final caveat here is that, even with sustainable financing, conservation is not guaranteed. Agreements must adapt to changing social and economic conditions, and in some cases contracts may become untenable because of sharp rises in opportunity costs.

\section{Conclusion}

We have reviewed current experience with direct payment applications and provided insights to clarify debate and aid practitioners. In developing a practical framework for design and implementation we have shown that the approach is highly adaptable but that it must have measurable and achievable conservation targets and well-organized local institutions. These conditions are not automatic and practitioners must respond creatively to the challenges and opportunities common to all conservation projects in developing countries. Thus, the approach represents an innovative tool for conservation but not a market for biodiversity services that transcends the complications of conservation and development.

We caution practitioners that direct payment contracts involve complex social and political challenges. There is no escape from participatory processes and significant investment is required to build relationships with local people, identify communities and resource claims, design institutions that can negotiate and implement contracts, and configure incentives and contracts appropriate to local conditions. Thus, in the context of uncertainty and weak legal frameworks, legitimacy is the most important condition for viable long-term agreements.

Finally, we suggest that the promise of direct payments lies in their ability to provide explicit, unambiguous incentives to local bodies and thus to motivate conservation action that is rapid and effective. Furthermore, the format of direct payments is significant for conservation at a global scale because it enables continuous funding to be channelled to local resource managers in return for the provision of demonstrated biodiversity conservation services.

\section{Acknowledgements}

We are grateful to colleagues from Conservation International, particularly P. Zurita and A. Bruner for detailed feedback and R. Rice for comments. We thank S. Wunder, T. Clements and M. Sommerville for excellent ideas and feedback. Professor W.M. Adams at the University of Cambridge provided essential advice and support, as did J. Welbergen. SM is grateful to the General Sir John Monash Foundation in Australia for financial support.

\section{References}

Adams, W., Aveling, R., Brockington, D., Dickson, B., Elliott, J., Hutton, J. et al. (2004) Biodiversity conservation and the eradication of poverty. Science, 306, 1146-1148.

AdAms, W. \& Infield, M. (2003) Who is on the gorilla's payroll? Claims on tourist revenue from a Ugandan National Park. World Development, 31, 177-190. 
Agrawal, A. \& Gibson, C. (1999) Enchantment and disenchantment: the role of community in natural resource management. World Development, 27, 629-649.

Asquith, N., Vargas, M. \& Wunder, S. (2008) Selling two environmental services: in-kind payments for bird habitat and watershed protection in Los Negros, Bolivia. Ecological Economics, $65,675-684$.

Balmford, A., Bruner, A., Cooper, P., Costanza, R. \& FARBER, S. (2002) Economic reasons for conserving wild nature. Science, 297, 950-953.

Balmford, A. \& Whitten, T. (2003) Who should pay for tropical conservation, and how could the costs be met? Oryx, 37, 238-250.

BERKES, F. (2004) Rethinking community-based conservation. Conservation Biology, 18, 621-630.

Brockington, D. \& Schmidt-Soltau, K. (2004) The social and environmental impacts of wilderness and development. Oryx, 38, $140-142$.

CFA (2006) Conservation Finance Alliance. Http://www. conservationfinance.org/index.htm [accessed 20 October 2007].

Cleaver, F. (2000) Moral ecological rationality, institutions and the management of common property resources. Development and Change, 31, 361-383.

Durbin, J., Volahy, A., Rakotombololona, W., AndrianANDrasana, H. \& RatsimbaZAFy, J. (2005) Menabe. Http://www.biaza.org.uk/resources/library/images/ o2Menabe.pdf [accessed May 2008].

Ellison, K. (2003) Renting biodiversity: the conservation concessions approach. Conservation in Practice, 4, 20-29.

Fairhead, J. \& Leach, M. (2003) Science, Society and Power: Environmental Knowledge and Policy in West Africa and the Caribbean. Cambridge University Press, Cambridge, UK.

Ferraro, P. (2001) Global habitat protection: limitations of development interventions and a role for conservation performance payments. Conservation Biology, 15, 990-1000.

Ferra ro, P. (2008) Global Conservation Payments Initiatives. Http:// www2.gsu.edu/ wwwcec/special/ci/index.html [accessed June 2008].

Ferraro, P. \& Kiss, A. (2002) Direct payments to conserve biodiversity. Science, 298, 1718-1719.

Ferraro, P. \& Pattanayak, S. (2006) Money for nothing? A call for empirical evaluation of biodiversity conservation investments. PLoS Biology, 4(4), e105. doi 10.1371/journal.pbio.0040105

Ferraro, P. \& Simpson, R. (2002) The cost-effectiveness of conservation payments. Land Economics, 78, 339-353.

GiCHOHI, H. (2003) Direct Payments as a Mechanism for Conserving Important Wildlife Corridor Links Between Nairobi National Park and its Wider Ecosystem: The Wildlife Conservation Lease Program. Conference Paper, 5th World Parks Congress, Durban, South Africa.

HARDNER, J. \& RICE, R. (2002) Rethinking green consumerism. Scientific American, 286, 70-77.

Harvey, P., Slater, R. \& Farrington, J. (2005) Cash transfersmere 'Gadaffi Syndrome', or serious potential for rural rehabilitation and development? Natural Resource Perspectives, Overseas Development Institute, 97, 1-4.

Hoт те, M. (2006) Amur Leopard and Tiger Conservation in a Social and Economic Context. Http://www.tigrisfoundation.nl/cms/ publish/content/downloaddocument.asp?document_id $=5$ [accessed September 2007].

Hutton, J., Adams, W. \& Murombedzi, J. (2005) Back to barriers? Changing narratives in biodiversity conservation. Forum for Development Studies, 32, 341-370.

KIss, A. (2004) Making biodiversity conservation a land use priority. In Getting Biodiversity Projects to Work: Towards More Effective
Conservation and Development (eds T. McShane \& M. Wells), pp. 98-123. Columbia University Press, New York, USA.

Landell-Mills, N. \& Porras, I. (2002) Silver Bullet or Fools' Gold? A Global Review of Markets for Environmental Services and Their Impact on the Poor. IIED, London, UK.

Lovera, S. (2004) Environmental Markets Impoverish the Poor. Katoomba Group's Ecosystem Marketplace. Http:// ecosystemmarketplace.com/pages/article.opinion.php? component_id=2268\&component_version_id=6448\&language $\mathrm{id}=12$ [accessed March 2008].

MCNEELY, J. (1993) Economic incentives for conserving biodiversity: lessons for Africa. Ambio, 22, 144-150.

Milne, S. (2007) Monitoring the Socio-economic Impacts of Conservation Incentives Agreements in Cambodia. Consultancy Report, Conservation International, Washington, DC, USA.

Mishra, C., Allen, P., McCarthy, T., Madhusudan, M., Bayarjargal, A. \& Prins, H. (2003) The role of incentive programs in conserving the snow leopard. Conservation Biology, $17,1512-1520$.

Missrie, M. \& Nelson, K. (2005) Direct Payments for Conservation: Lessons from the Monarch Butterfly Fund. Research Summary/ Paper No. 8. College of Natural Resources, University of Minnesota, Minneapolis, USA.

Murphree, M. (1994) The role of institutions in community-based conservation. In Natural Connections: Perspectives in Communitybased Conservation (eds D. Western, M. Wright \& S. Strum), pp. 403-427. Island Press, Washington, DC, USA.

Niesten, E. \& Rice, R. (2004) Sustainable forest management and conservation incentive agreements. International Forestry Review, $6,56-66$.

Ostrom, E. (1990) Governing the Commons: The Evolution of Institutions for Collective Action. Cambridge University Press, Cambridge, UK.

Pagiola, S., Agostini, P., Gobbi, J., de Haan, C., Ibrahim, M., Murgueitio, E. et al. (2004) Paying for Biodiversity Conservation Services in Agricultural Landscapes. Report. Environmental Economics Series, The World Bank Environment Department, Washington, DC, USA.

Pagiola, S., Bishop, J. \& Landell-Mills, N. (eds) (2002) Selling Forest Environmental Services: Market-based Mechanisms for Conservation and Development. Earthscan, London, UK.

Robinson, J. (2006) Conservation biology and real-world conservation. Conservation Biology, 20, 658-669.

Romero, C. \& Andrade, G. (2004) ICO approaches to tropical forest conservation. Conservation Biology, 18, 1454-1455.

RSPB (Royal Society for Protection of Birds) (2009) Save the Sumatran Rainforest. Http://www.rspb.org.uk/supporting/ campaigns/sumatra/ [accessed May 2009].

Salafsky, N., Margoluis, C., Redford, K. \& Robinson, J. (2002) Improving the practice of conservation: a conceptual framework and research agenda for conservation science. Conservation Biology, 16, 1469-1479.

SCB (Society FOR Conservation BIOlOgy) (2002) Society for Conser vation Biology 16th Annual Meeting Abstracts for Symposium 2: Direct Payments as an Alternative Approach to Conservation Investment. Conference Proceedings, Society for Conservation Biology, 16th Annual Meeting, Kent, UK.

Schubert, B. \& Slater, R. (2006) Social cash transfers in lowincome African countries: conditional or unconditional? Development Policy Review, 24, 571-578.

Simpson, R. \& SEDJo, R. (1996) Paying for the conservation of endangered ecosystems: a comparison of direct and indirect approaches. Environment and Development Economics, 1, 241-257. 
Svadlenak-Gomez, K., Clements, T., Foley, C., Kazakov, N., Lewis, D., Miquelle, D. \& Stenhouse, R. (2007) Paying for Results: WCS Experience with Direct Incentives for Conservation. TransLinks, WCS, New York, USA. Http://www.translinks.org/ ToolsandTrainingMaterials/tabid/2064/language/en-GB/Default. aspx [accessed May 2008].

Swar T, J. (2003) Will direct payments help biodiversity? Science, 299, 1981.

Van Acker, F. (2003) Cambodia's Commons: Changing Governance, Shifting Entitlements? Discussion Paper No. 42. Centre for ASEAN Studies, Antwerp, Belgium.

VIRA, B. (2001) Claiming legitimacy: analysing conflict in the environmental policy process. Government and Policy, 19, 637650.

WCCSA (Western Cape Conservation Stewards Association) (2006) Cape Stewardship. Http://capestewardship.co.za/content/view/ 254/228/ [accessed September 2007].

Western, D., Wright, M. \& Strum, S. (eds) (1994) Natural Connections: Perspectives in Community-Based Conservation. Island Press, Washington, DC, USA.

Wilkie, D., Morelli, G., Demmer, J., Starkey, M., Telfer, P. \& Steil, M. (2006) Parks and people: assessing the human welfare effects of establishing protected areas for biodiversity conservation. Conservation Biology, 20, 247-249.

WTW (2007) Watamu Turtle Watch. Http://www.watamuturtles. com/WTW_Programmes.htm [accessed October 2007].
W under, S. (2005) Payment for Environmental Services: Some Nuts and Bolts. Occasional Paper No. 42. Centre for International Forestry Research, Bogor, Indonesia.

W Under, S. (2006) Are direct payments for environmental services spelling doom for sustainable forest management in the tropics? Ecology and Society, 11(2), 23. Http://www.ecologyandsociety.org/ voli1/iss2/art23/

W UNDER, S. (2007) The efficiency of payments for environmental services in tropical conservation. Conservation Biology, 21, 48-58.

\section{Biographical sketches}

Sarah Milne researches the social and political aspects of conservation and development, both at the practical field level and in the context of global policy-making. Her PhD focuses on a set of direct payment agreements initiated by Conservation International in the Cardamom Mountains, south-west Cambodia. There, she conducted ethnographic research into the practices and impacts of transnational biodiversity conservation. EDUARD Niesten focuses on implementing conservation projects using incentive-based approaches and integrating such approaches into economic development strategy. $\mathrm{He}$ also supplies economics expertise to a broad range of conservation interventions such as protected area planning and establishment, design of forest-carbon sequestration arrangements, and communitylevel conservation initiatives. His research focuses on property rights and incentives for conservation. 